\title{
VIRTUAL COMMUNITY FOR A CREATIVE CITY
}

\author{
Zigigiew PrZYgodZKi, Ewelina Kina \\ Department of Regional Economy and Environment, Faculty of Economics and Sociology, \\ University of Łódź, Poland
}

Manuscript received: December 9, 2014

Revised version: February 24, 2015

Przygodzki Z., Kina E., 2015. Virtual community for a creative city. Quaestiones Geographicae 34(2), Bogucki Wydawnictwo Naukowe, Poznań, pp. 65-74, 4 figs. DOI 10.1515/quageo-2015-0016, ISSN 0137-477X.

\begin{abstract}
Cities provide conditions for the development of creativity and creative capital; some cities have made it an area of strategic intervention. Surely, there is a strong link between the creativity of a city and the value of social capital in a given territory. Hence, it is vital to answer the following questions: To what extent does investment in human capital determine the value of creative capital? What to invest in? Can one invest efficiently taking advantage of the attractive and popular virtual space? These are the questions explored by the present authors. Their specific goal is to assess the importance of social networks as a modern ICT tool for establishing relations, and of open networks in the dissemination of knowledge and in the development of creative communities.
\end{abstract}

KEY wORDS: virtual community, creative cities, social capital, social media, social networks, virtual networks

Address of the corresponding author: Ewelina Kina, Department of Regional Economy and Environment, Faculty of Economics and Sociology of the University of Łódź, Rewolucji 1905 r. 39, 90-214 Łódź, Poland; e-mail: ewelina_kina@uni.lodz.pl

\section{Introduction and research objective}

Information society (Castells 2010) has created a new space which develops continuously, even spontaneously. It does not fully replace previous relations, events or activities. Undoubtedly, the virtual and the real world intertwine and become interdependent, or sometimes they compete. This is possible, first of all, because real values are generated in a virtual space, which has become a relevant "place" and way of investing in resources and creating capital, including territorial capital (Markowski 2013). Social capital is one of its key assets. This is where we can easily observe links between the virtual and the real world; furthermore, for development policy it is a potential area of intervention. By linking these elements, we planned and conducted a study aimed at assessing the importance of social networks as a modern information soci- ety tool to create relations and open networks in knowledge dissemination and developing creative communities in a city. Considerations were deliberately limited to the creative sector (The Economy of Culture in Europe 2006), mostly because recently this is the area frequently and universally addressed in development policy, with a clear local flavour relating to the history and identity of a place. The idea of creative cities (Landry 2008, Klasik 2008) has become one of possible development strategies for modern cities. Creativity, like human capital, is a potential asset that can be used in determining social and economic development of a city. Theoretically, any city may provide conditions for the development of creative activities. The creativity of a city can be determined by an increased value of its social capital. We also sought to find out to what extent investment in social capital determines the value of creative capital. 
The thesis adopted in the paper is that social capital determines the value of human capital mainly by its influence on communication processes. However, its aim is to answer the question of whether virtual networks - which use a borderless network as a communication channel and a place for building relations - are in fact local. In other words, it is capital built in a virtual space and consumed locally. In the local perspective, investment in developing relations in a virtual space may be profitable, i.e. it may bring concrete profits to the local community. The problem in extenso has become the subject of the authors' research work.

\section{Determinants of growth of creative cities}

Creativity denotes creative capabilities of the mind which determine the development of new ideas and concepts leading to original solutions. The feature is characteristic of people with a lot of imagination, artistic or intellectual resourcefulness. Innovativeness, the contemporary paradigm of development, is often identified with creativity. In this case, however, despite a strong link between the two, we must remember about differences which, when understood, help us to achieve the final outcome - the building of innovation capacity - more effectively. Creativity is a divergent process of thinking which generates ideas. The process is hard to measure or evaluate, or is even immeasurable. Innovativeness is a convergent process focused on selecting and implementing certain new ideas into the economy. Creativity can be identified with producing ideas, while innovativeness means the ability to implement them (Landry, Bianchini 1995). Simplifying, we may say that creativity is a process in which new ideas are created, while innovativeness is the process of their implementation. Creativity is a precondition for innovativeness, but it is innovativeness which maximises the human potential of cities and regions (Creative Economy Report 2010). In this perspective, both creativity and innovativeness have their economic value (Throsby 2001).

Creativity is an inherent feature of each and every human being which serves to identify "the ability to create new things, new ways of prob- lem-solving" (Kuźnik 2008). The above does not mean, however, that everybody is creative. Nevertheless, this characteristic can be shaped by investing in elements which mobilise, stimulate, or even provoke creativity.

Considering appropriate areas to invest in creativity, we can use the idea of a creative city ${ }^{1}$. Its foundations were worked out by C. Landry, who argued that people were the key resource of a city. Human capital replaces location, natural resources and access to markets with creativity, which becomes the key to urban development dynamics (Creative Economy Report 2010). Creativity becomes a city resource (Landry 2011). The central element of the idea of a creative city is culture, which generates a specific climate highly appreciated by creative individuals. It is often decisive for the brand of a city (Sokołowicz 2013). Culture is now seen as the magic substitute for all the lost factories and warehouses, and as a device that will create a new urban image, making the city more attractive to mobile capital and mobile professional workers (Hall 2000). Creativity and specific forms of expression are provoked by social and spatial relationships shaped in a creative environment of a city. "The creative milieu is like a river which runs through a stylised economic and social landscape" (Hall 2000: 645). The properties of the local milieu thus defined determine the dynamics of production and employment on the local market. The core of a creative city includes basic sectors of local culture, the importance of which is reinforced by the presence of complementary activities performed, e.g., by designers, interior decorators, artists, or software engineers. Relationships accompanied by the exchange of knowledge, information and experi-

\footnotetext{
The idea of a creative city emerged in the late 1980s in response to the crisis of the cities of those times, which had to undergo restructuring as a result of global changes in trade on Eastern markets. The idea gained in popularity in the 1990s. It was based on the basic assumption that each locality has got a potential much bigger than just the assets visible at first glance. Each city may provide conditions for the development of creative activities. The idea assumes that each city should create conditions attractive enough for its inhabitants to contribute to planning, thinking and stimulating imagination. Ordinary people can do unusual and creative things, so assuming that everybody could improve their creativity by at least $5 \%$, economic development of a city would change dramatically (Creative Economy Report 2010).
} 
ences among these spheres generate the dissemination of positive effects of their operation. The local labour market is another determinant of the creativity of a city. Its structure and processes embrace various creative stimuli reflected in human relations within the employment system.

These three elements of a city's creative economy should be discussed in a broader context of conditions identified as (Scott 2010: 126):

- the local system of traditions, norms and heritage; this is the way in which tacit knowledge is transferred, knowledge preserved in the identity and traditions of a local community, which determines the main directions of creative activities;

- the image of a city, which reflects and supports creative ambitions by a specific image preserved among internal and external recipients of the city's offer;

- a space for leisure, an important element of a city's attractiveness for creative inhabitants;

- a neighbourhood adjusted to the needs of a creative community which offers appropriate accommodation and infrastructure;

- educational activities, which play an important role in supplying specialists to the local labour market;

- extended social networks, which complement interpersonal contacts at work, enrich workers' know-how and other useful specialist knowledge.

The outermost sphere decisive for the sustainability of a creative city comprises: the institutional platform of a local community, social contracts, the system of shared norms, the scope of governance, and the public-social-private partnership (Scott 2010).

Thus, we may note that social capital is of primary importance for the development of creative cities since it directly influences the rate and dynamics of growth in a given location. Resources of social capital directly depend on the quality of human capital and cultural capital as described by J. Colleman. The determinants of the growth dynamics of creative cities are space-specific and depend on unique properties of local entrepreneurship milieus and on the type of creative city. There are various types of creative cities: technological-innovative, cultural-intellectual, cultural-technological, and technological-organisational (Hospers 2003). Creative cities utilise their creative potential in different ways and at various levels (Creative Economy Report 2010). They also adopt various investment strategies. Some cities pay most attention to an improvement and extension of infrastructure that will support arts, artists and their activities. Other cities directly support the potential of a creative urban economy by investing mostly in three main fields: arts and cultural heritage, media and industrial entertainment, and creative services for business. Design, advertising and entertainment are often perceived as innovation drivers for the entire urban economy which may effectively shape the so-called experience economy ${ }^{2}$. Moreover, the creativity of a city is reinforced with investments designed to develop a strong creative class. The idea indicates that contemporary economies shift from a system based on corporations to one focused on individuals, meaning we should strive to develop conditions attractive mainly for people, not only for business. The specific climate of a location attracts the creative class, which, in turn, becomes a stimulus for the economic development of the area. Another strategy is that of a holistic approach which accumulates all earlier motivations for activity. In this approach, a creative city is considered an integrated system of different organisations and cultures operating around the public and private sectors and NGOs. In this context, the competitiveness of a creative city is demonstrated not only in the development of the creative sector and its specific potential, but also in differentiation and operational dynamics (Petrikova et al. 2013). Landry stresses in his writings that networks are indispensable to develop a system capable of reflexive learning and generating innovation. However, it is also remarkable that many traditional networks do not contribute importantly to the development of urban creativity as they do not meet the requirements of contemporary urban communities ${ }^{3}$. They are used only for communication among narrow groups

2 Experience economy - according to the theory, the physical value of a product depends not on its price but on experience resulting from its use. The concept assumes that experience is currently a very important product and that to ensure the attractiveness of a product or service offered we need to expand experiences connected with it. For more, see Pine and Gilmore (1999).

3 Communities which represent high mobility, cultural, ethnic and religious diversity, and different lifestyles. 
of inhabitants, often closed to the external world. In this context Florida (2003) very categorically concluded that the theory of "social capital" should be replaced with the theory of a "creative capital" - a derivative of the theory of "human capital". He argued that strong interpersonal relations weakened the ability of a local community to internationalise, that they posed a barrier to newcomers, to mobile, creative individuals. Locations with human capital representing weak ties (Granovetter 2001) ${ }^{4}$ are more friendly to newcomers and, as such, more effectively determine innovation processes. However, it is hard to accept this viewpoint uncritically, especially in the light of such a narrow definition of social capital adopted by the author. Also observations of various social and economic phenomena indicate that the existence of ties, trust and active participation in networks of relations open to extra-local environment is a precondition for maintaining the competitiveness of creative cities (Landry 2008). At present these networks are often virtual (e.g., virtual communities, discussion platforms, social networks), and they lead to informal institutional partnerships between public, private and social institutions. The networks often connect people who are renowned and respected experts in their communities, but who do not know one another (Landry 2008). Such virtual encounters are not biased with any hierarchy or subordination, not restricted with official, formal behaviour. They are also inspiring and motivating for usually withdrawn and introvert individuals, closed to social relations but with a considerable creative potential. It is because of the intimacy they may retain when communicating with others through tools which do not require face-to-face contacts.

\section{Integration and the causative role of social capital in urban space}

A comprehensive explanation of economic growth also calls for paying particular attention to social phenomena since any human activity is embedded in a concrete territory, environment,

4 Granovetter's notion of the "strength of weak ties" is considered a feature of contemporary society. The author is of the opinion that unsustainable forms of association and networks of superficial acquaintances are more useful to people than long-lasting ties. community with its own culture, and norms and values that affect the economy. Social capital, by definition, integrates entities, activities and actions. It improves the productivity of all resources used for development. It also allows enjoying advantages as a result of an improved efficiency of actions, of operating in a network covering a concrete territory. Interactivity, mutuality of actions among the entities involved, releases strong synergy effects, such as collective learning by using so-called tacit knowledge and human capital, which directly translates into the entrepreneurship of a regional community (Kilpatrick et al. 2002, Pietrzyk 2000, Vaňová et al. 2010, Making creative-knowledge cities 2010).

Already P. Bourdieu when defining social capital pointed to the ability to combine actual and potential resources possible because of mutual relations among the participants of a network. The network is important as it gives individuals access to the resources of other participants. Membership in a network, as Bourdieu points out, creates the feeling of a "collectively owned capital". The vision of achieving benefits creates social ties and makes individuals adopt collective, solidarity-based types of behaviour. The mere participation in a network lets people act in a community, creating a sense of approval (Kilpatrick et al. 2001). Interestingly, social capital is a series of different collections where the existence of common social structures facilitates the activities of individuals and organisations (Grootaert 1998).

Social capital is also expressed in trust, which, on the one hand, is a cultural norm but, on the other, is a primary characteristic of exchanges between different entities. Risk socialisation and higher predictability of partners' behaviour importantly determine economic collaboration. In other words, it also enables the development of clusters, which Landry thinks is extremely important as "Clusters of talents, skills and infrastructure provide the basis for a "creative economy' and a creative community" (Landry 2008: 38). This author also stresses that one of the most important assets of a creative city is leadership, which determines its growth potential. It is a common characteristic of all creative cities that there are visionaries able to select precise development directions. Their activities are effective when they operate in a political culture capable 
of effectively delivering identified goals and are surrounded by creative organisations. Such institutional efficiency requires social trust and advanced forms of cooperation and partnership. Thus, we speak of social capital which is the driving force in cities (Jewtuchowicz 2005).

\section{The importance of social networks for the development of a creative community}

All the processes, phenomena and activities which influence a creative city are part of information economy and society. Their primary distinguishing factor is information and communication technologies (ICT), which modify the way individuals, organisations and communities operate.

In the context of our considerations, we studied the activities of NGOs on social networking sites. The latter were listed as tools to build up informal cooperation networks, valuable from the point of view of investing in the development of a creative city. The objective of the study was to assess the importance of social networking sites for the diffusion of knowledge and for building networks of contacts and collaboration. The study included NGOs operating in selected cities in the Łódź Metropolitan Area (LMA).

Since a creative city needs creative organisations open to cooperation, we first tested their inclination to be active in social networks. That was the starting point for the evaluation of the use of ICT tools in enhancing communication, cooperation, diffusion of knowledge, and building relationships. We studied NGOs ${ }^{5}$ in all towns and cities of the Łódź sub-region with the exception of Łódź itself. On the basis of quasi-participant observation and the desk research method, in the early stages of the study the inclination was assessed as low (out of the 564 NGOs studied in 11 towns of the LMA, only 88 were found on Facebook.com, the most popular social networking site) $)^{6}$. Respondents for in-depth personal interviews were selected. Those chosen were organisations which were active on the site in question

\footnotetext{
5 The list of NGOs was drafted from the NGO database available on the official site www.ngo.pl (accessed in July 2012).

6 More about the methodology in Kina (2014).
}

within the previous six months, which were not a branch of an organisation based in another city, and which delivered tasks in various areas of particular importance for the social and economic development of their unit. Finally, eleven NGOs qualified for the second stage representing seven cities. Unfortunately, also among them social networking sites were little popular (only two organisations declared using other social networking services, such as Twitter and NK.pl). On the other hand, an analysis of the frequency of using the sites showed that a clear majority of the tested population $(73 \%)$ logged onto the site at least once a day. The relatively low interest in the use of other sites as a friendly environment for an exchange of knowledge and information and for building relations may have resulted from a low awareness of the possibilities they created.

Among reasons that guided individual NGOs when they signed up for particular services (Fig. 1 ), priority was given to their universality (they are universally used by the society) and popularity (it is trendy to be active in a network, which improves an organisation's image). Other motives included the global reach of a service, easy access at any place and time, and the promotion of one's operations. Although the answers did not explicitly indicate the possibility of sharing information and knowledge or establishing cooperation, we may conclude that the universal presence of such services in a community and in other organisations can indirectly reflect the subconscious wish to establish contacts with the biggest number of units. On top of that, to complement this part of the analysis with current reasons for which a social networking service is used (after at least a year of use), we can see a clear re-evaluation.

Self-presentation and the promotion of one's individual actions still remain at the top of the list, but with the acquisition of a better perspective as to the social networking site, its specificity, services and possibilities, more and more organisations pay attention to communication and the opportunity to collaborate with the community (8 respondents) and with other NGOs (6 out of the 11 NGOs in the study; Fig. 2).

Hence, there are some positive tendencies and people have become aware what possibilities open up for them in social networks with respect to developing social relations (fostering 


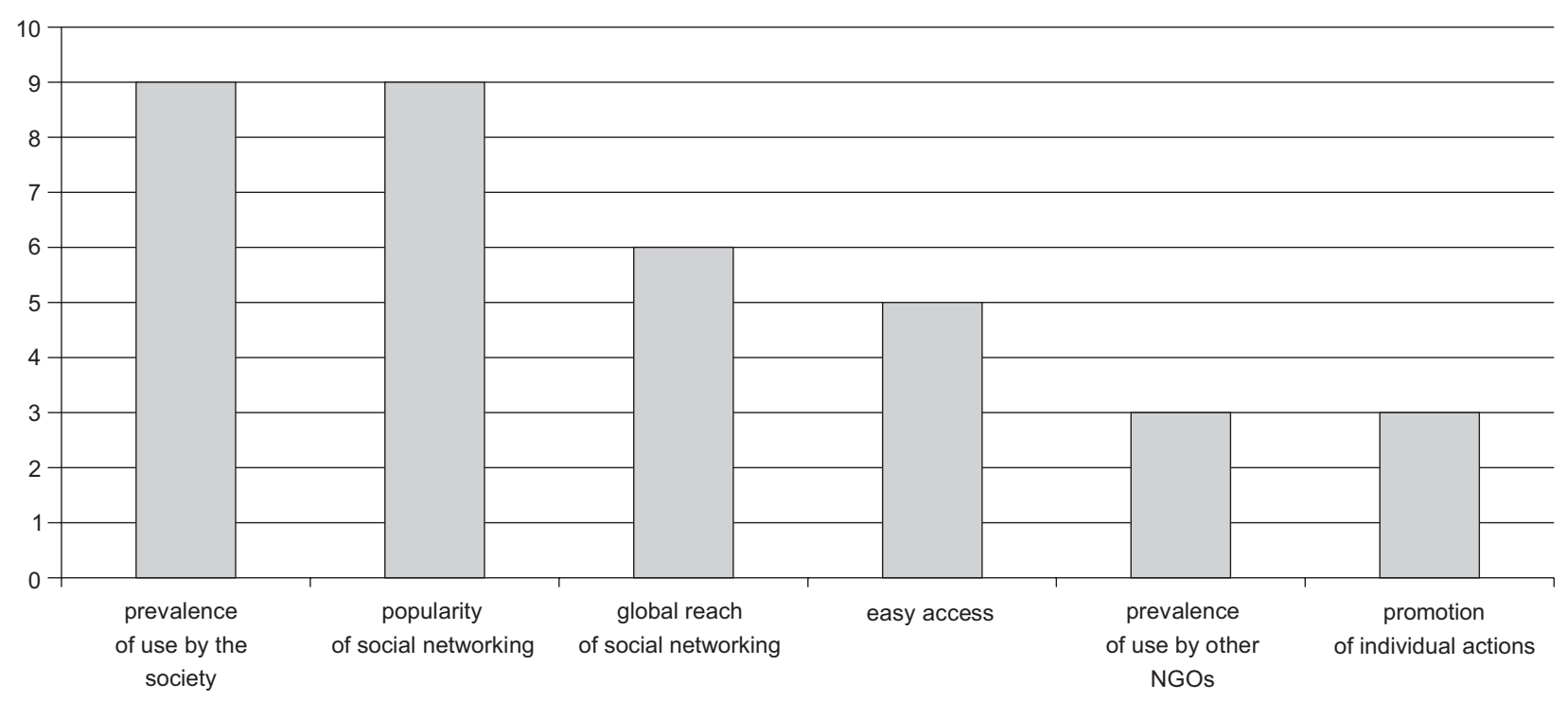

Fig. 1. Reasons for activity on social networking sites.

social capital). They encourage a further analysis of the scope and nature of the ties and cooperation determined by one's activity on the site. All NGOs declared that by using social networking they had managed to establish new contacts (they shared information, events, experiences, etc.) and launched cooperation (partnerships in delivering common activities, involvement in joint undertakings, voluntary work, etc.) with other organisations and units (in particular with local community - all the 11 NGOs). Other NGOs and local authorities ranked second in this classification. The collected data provide evidence for a stronger tendency among the analysed NGOs to undertake joint actions rather than to simply share information (Fig. 3).

This is highly promising in the context of shaping social capital. Joint involvement in ac- tions offers a higher probability and chances of mobilising individual creativity, generating their individual value while achieving a common goal.

Importantly enough, people most engaged in collaboration with NGOs are youngsters, students, energetic and resourceful individuals forming the core of the creative class, willing to act and share their knowledge. Politicians ranked second, which is also positive if we bear in mind that a creative city needs leadership open to partnerships and to broad collaboration in advanced forms. Relations established through social networking sites are either long-term or incidental (on a single occasion under a concrete project). Theoretically, such a distribution may be positive. On the one hand, strong internal ties can create obstacles to building up individual creativity as they are open to the external world. On the

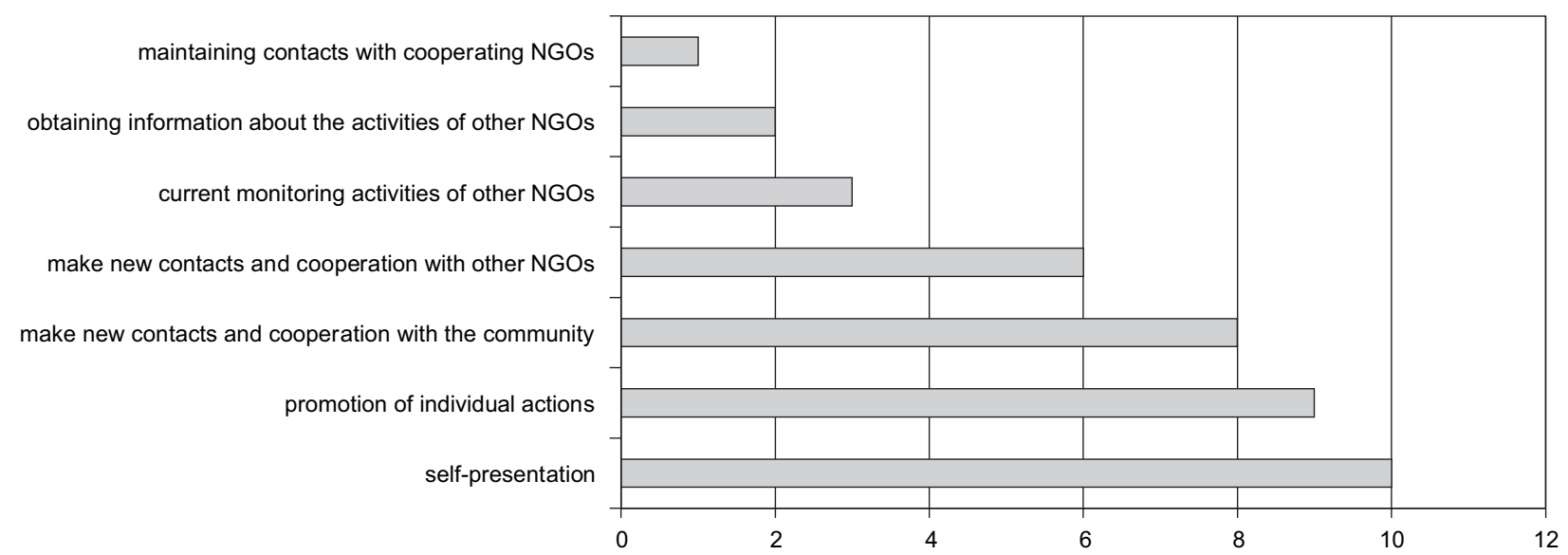

Fig. 2. Objectives of activity on social networking sites. 
other hand, they may generate more intense development of individuals clustered in a network based on such ties because they are much more willing to exchange resources. Speaking of shortterm, occasional relations, it is argued that weak ties are more favourable to developing broad collaboration and knowledge diffusion since parties to them are more open to the external world. The nature of relations depends, among other things, on the unit with which the ties are established. With respect to representatives of the local community, a vast majority of NGOs (8 respondents) declared long-term collaboration (more than 6 months). The respondents highlighted regular involvement of the community in joint actions, voluntary work, promotion, and information campaigns. Occasional collaboration on a concrete project is most typical of activities undertaken in agreement with other NGOs (the answer selected by 4 respondents).

Although the tools analysed in the study (social networking sites) are non-spatial by nature and not 'bound' with one single territory, an analysis of the location of parties that contact each other most often shows something different. Getting rid of geographical boundaries which determine the scope of cooperation is often mentioned as the biggest benefit and success of using ICT. The possibility of unlimited, global collaboration and access to knowledge is the most desirable outcome of the development of ICT tools. They enable the creation of a milieu open to the external environment facilitating free movement of resources, especially intangible ones: knowledge, ideas, information. They generate milieus open to the external world. However, an analysis of the research data collected shows that the units communicating within social networks most often are those based in the same location. As many as 63\% of the organisations interviewed stated that most of their 'acquaintances' on the social networking site came from the same town. The conclusion is that information, knowledge and cooperation networks established as a result of communication and activities in a social network determine the value of local social capital. It shows that social networks can equally well and successfully generate positive outcomes and participate in the diffusion of knowledge within a city (the territorial unit studied). Thus, although the processes we analysed are virtual, they are clearly embedded in a given territory, a local community, and they may have an impact on the real functioning of the city. Benefits may be even greater if the relations initiated within a social network are transferred into the real world. For the majority of our respondents that was the actual course of events. We have not identified any specific conditions which determine such a transfer and which surely must be there, but 9 out of the 11 NGOs

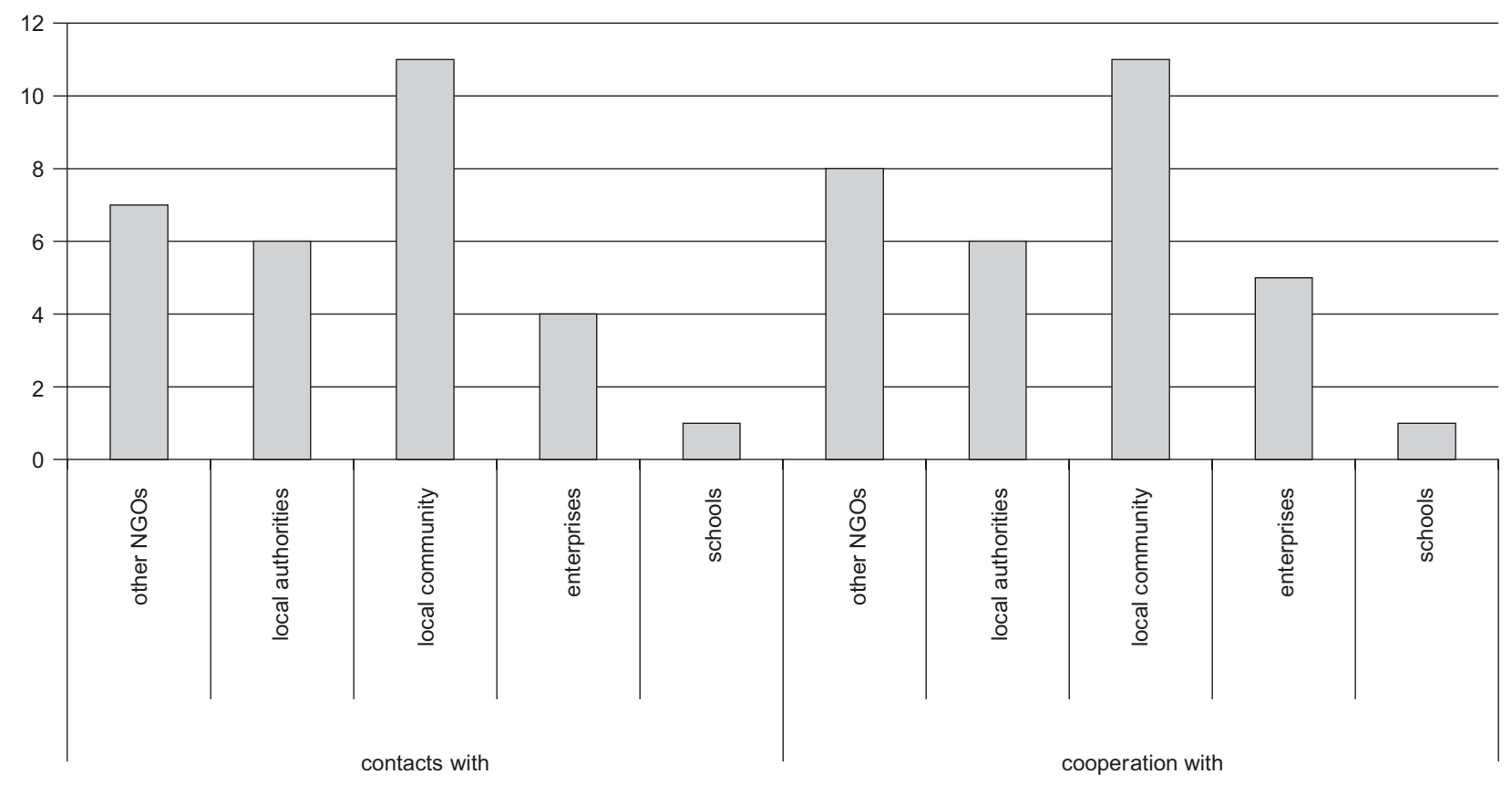

Fig. 3. Relations and cooperation resulting from activity on social networking sites. 
confirmed the transfer of activities into the real world. One organisation rejected the thesis and one reported a reverse tendency, that real-world activities and collaboration were transferred to the virtual world. Then a social network becomes a tool that maintains the already existing cooperation and established contacts. Almost $60 \%$ of the respondents who confirmed the transfer of contacts established in the network to the real world concluded that physical engagement was usually cyclical (organisations from time to time get engaged in selected projects).

One important question remains to be answered: what are these social network-based contacts and relations about? Can we distinguish concrete types of knowledge which can, to a greater or smaller extent, be transferred through the networking service to reach the participants of the developed network of contacts and collaboration?

In accordance with a functional division of knowledge, the most frequently exchanged type of knowledge included basic facts about what other entities in the network did (although the possibility to monitor and control the activities of other NGOs or acquiring updated data about the activities of other NGOs were not among the most often selected main goals of being in a network). It was followed by knowledge concerning certain rules in a given community. Social networking sites were the least important for the diffusion of expert knowledge and knowledge of relations. While the low share of the former is due to general specificity (knowledge accumulated by experts, of limited public access), the small proportion of the know-who type of knowledge in the transfer is rather worrying. The mere presence in a network should facilitate access to in-

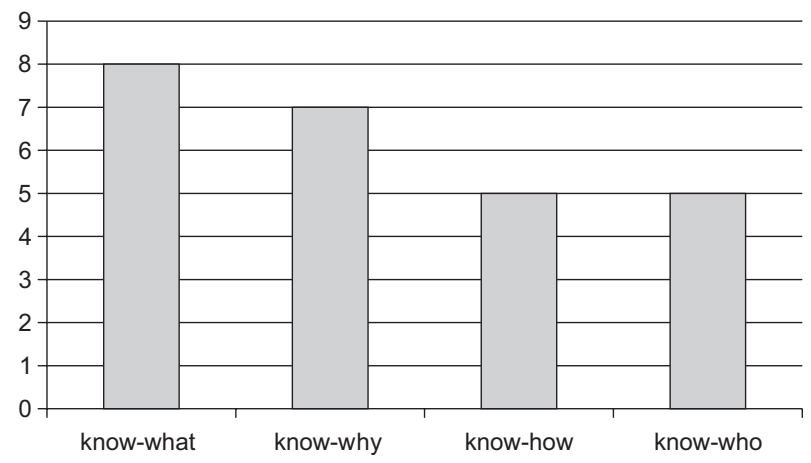

Fig. 4. Types of transferred knowledge. formation about who has got knowledge useful to its members (Fig. 4).

On the basis of the study, we may suggest some general conclusions in the context of their importance for the development of a creative city. Although social networks are not common tools for NGOs to establish relations and launch cooperation, they offer a very big potential. They also mobilise them to exchange knowledge and to collaborate (also in real life). The above concerns mostly young people from the same town, which is important for the development of specific resources.

\section{Conclusions}

A creative city is a specific development concept which does not exist by itself, but requires well-thought-out activities that can be delivered only in a supportive environment. In a knowledge-based economy, the environment often takes on a new dimension, a virtual one. By an effective use of this channel, we may influence urban development processes. An opportunity is offered by social networking sites. They are an important tool for the creation of collaboration networks open to the diffusion of knowledge which operate virtually, but which are also embedded in the local specificity of the area. They play an important role in shaping a creative milieu. In the analysed example we can see that networks are still little used to influence urban economies and their stakeholders. But on the other hand, the results show the huge potential of virtual space which directly affects the real life of inhabitants.

We may conclude that the organisations covered by the study use the virtual world relatively rarely in their operations. Simple promotion excepting, relations in the sense of social capital are rarely built in this way. This, however, is not evidence of a low effectiveness of such activities, but only confirms that such tools are little used.

In sum, interestingly enough, the participants of a virtual space tend to engage in activities or concrete actions rather than share various types of information and knowledge. This is a hint telling us how effective messages are and what is the goal of using social media in building social capital. The results of our study also allowed us to 
observe the so-called "local dimension of virtual relations and networks", which is of paramount importance for the return of the locally paid costs of such an investment.

\section{References}

Castells M., 2010. Spoteczeństwo sieci (The Rise of the Network Society). PWN, Warsaw.

Creative Economy Report, 2010. United Nations.

Florida R., 2003. Cities and the creative class. City and Community 2 (1): 3-19.

Granovetter M. S., 2001. The strength of weak ties. American Journal of Sociology 78 (6): 1360-1380.

Grootaert C., 1998. Social capital: The missing link? The World Bank, Social Capital Initiative, Working Paper No. 3, $1-24$.

Hall P., 2000. Creative cities and economic development. Urban Studies 37 (4), 639-649.

Hospers G.J., 2003. Creative cities in Europe: Urban competitiveness in the knowledge economy. Intereconomics 38 (5): 260-269. Online: http:// hdl.handle.net/ 10419/41712, p. 262, (accessed 3 October 2013).

Jewtuchowicz A., 2005. Terytorium i wspótczesne dylematy jego rozwoju (A territory and modern dilemmas of its development). Wydawnictwo Uniwersytetu Łódzkiego, Łódź.

Kilpatrick S., Field J., Falk I., 2001. Social capital: An analytical tool for exploring lifelong learning and community development. British Educational Research Journal 29 (3), 417-433.

Kilpatrick S., Loechel B., Thomas S., Woinarski Z., 2002. Generating jobs in regional Tasmania: A social capital approach. Final Report, University of Tasmania.

Kina E., 2014. Wpływ sieci społecznościowych na wartość kapitału ludzkiego $\mathrm{w}$ regionie łódzkim (Effect of social networks on the value of human capital in the Łódź region). In: Przygodzki Z. (ed.), Kapitat ludzki w regionie tódzkim. Społeczeństwo, edukacja, przestrzeń. Wydawnictwo Uniwersytetu Łódzkiego, Łódź.

Klasik A., 2008. Kreatywne i atrakcyjne miasta. Koncepcje i mechanizmy restrukturyzacji aglomeracji miejskich (Creative and attractive cities. Concepts and mechanisms of restructuring of urban agglomerations). In: Klasik A. (ed.), Kreatywna aglomeracja - potencjaty, mechanizmy, aktywności. Podejścia metodologiczne. Wydawnictwo Akademii Ekonomicznej, Katowice.
Kuźnik F., 2008. Modele kreatywnej aglomeracji miejskiej (Models of a creative urban agglomeration). In: Klasik A. (ed.), Kreatywna aglomeracja - potencjaty, mechanizmy, aktywności. Podejścia metodologiczne. Wydawnictwo Akademii Ekonomicznej, Katowice.

Landry C., 2008. The creative city. A toolkit for urban innovators. $2^{\text {nd }}$ edition. Narodowe Centrum Kultury, Warszawa.

Landry C., 2011. Creativity, culture $\mathcal{E}$ the city: A question of interconnection. Supported by the Ministry of Family, Children, Youth, Culture and Sport of the State of North Rhine-Westphalia.

Landry C., Bianchini F., 1995. The creative city. Demos Paper No. 12, London.

Markowski T., 2013. Planowanie i zarządzenie w obszarach funkcjonalnych: dylematy i wyzwania (Planning and management in functional areas: dilemmas and challenges). Conference on Polityka miejska a przyszłość planowania przestrzennego.

Making creative-knowledge cities. A guide for policy makers, 2010. Musterd S., Brown J., Lutz J., Gibney J., Murie A. (eds), ACRE project. Amsterdam Institute for Social Science Research, University of Amsterdam

Petrikova K., Vanova A., Borsekova K., 2013. The role of creative economy in Slovak Republic. Springer-Verlag London: AI \& Soc. DOI 10.1007/s00146-013-0508-5.

Pietrzyk I., 2000. Polityka regionalna Unii Europejskiej i regiony w państwach członkowskich (Regional policy of the European Union and regions in the member states). PWN, Warsaw.

Pine B.J., Gilmore J.H., 1999. The experience economy: Work is theatre \& every business a stage. Harvard Business School Press, Boston.

Scott A. J., 2010. Cultural economy and the creative field of the city. Geografiska Annaler, Series B: Human Geography, 92: 115-130.

Sokołowicz M.E., 2013. Is the community of Łódź informed about living in a creative city? City of Łódź' branding strategy and its perception. Studia Ekonomiczne. Zeszyty Naukowe Uniwersytetu Ekonomicznego w Katowicach, 149: 256-267.

Sztompka P., 2002. Socjologia. Analiza społeczeństwa (Sociology. An analysis of a society). Wydawnictwo Znak, Kraków.

The economy of culture in Europe, 2006. Report for the European Commission, KEA European Affairs.

Throsby D., 2001. Economics and culture. Cambridge University Press, Cambridge.

Vaňová A., Borsekova K., Foret M., 2010. Importance of partnership and cooperation for territorial development. Theoretical and Applied Economics XVII (10): 73-82. 
